\title{
Targeting E3 Ubiquitin Ligases and Deubiquitinases in Ciliopathy and Cancer
}

\author{
Takashi Shiromizu ${ }^{1}$, Mizuki Yuge ${ }^{1}$, Kousuke Kasahara ${ }^{2}{ }^{\mathbb{D}}$, Daishi Yamakawa ${ }^{2}$, \\ Takaaki Matsui $^{3}$, Yasumasa Bessho ${ }^{3}$, Masaki Inagaki ${ }^{2}$ and Yuhei Nishimura ${ }^{1, *}$ \\ 1 Department of Integrative Pharmacology, Graduate School of Medicine, Mie University, Tsu, \\ Mie 514-8507, Japan; tshiromizu@doc.medic.mie-u.ac.jp (T.S.); 320d030@m.mie-u.ac.jp (M.Y.) \\ 2 Department of Physiology, Graduate School of Medicine, Mie University, Tsu, Mie 514-5807, Japan; \\ kkasahara@doc.medic.mie-u.ac.jp (K.K.); dyama@doc.medic.mie-u.ac.jp (D.Y.); \\ minagaki@doc.medic.mie-u.ac.jp (M.I.) \\ 3 Gene Regulation Research, Division of Biological Sciences, Nara Institute of Science and Technology, \\ Takayama, Nara 630-0192, Japan; matsui@bs.naist.jp (T.M.); ybessho@bs.naist.jp (Y.B.) \\ * Correspondence: yuhei@doc.medic.mie-u.ac.jp; Tel.: +81-(59)-231-5006; Fax: +81-(59)-232-1765
}

Received: 31 July 2020; Accepted: 17 August 2020; Published: 19 August 2020

\begin{abstract}
Cilia are antenna-like structures present in many vertebrate cells. These organelles detect extracellular cues, transduce signals into the cell, and play an essential role in ensuring correct cell proliferation, migration, and differentiation in a spatiotemporal manner. Not surprisingly, dysregulation of cilia can cause various diseases, including cancer and ciliopathies, which are complex disorders caused by mutations in genes regulating ciliary function. The structure and function of cilia are dynamically regulated through various mechanisms, among which E3 ubiquitin ligases and deubiquitinases play crucial roles. These enzymes regulate the degradation and stabilization of ciliary proteins through the ubiquitin-proteasome system. In this review, we briefly highlight the role of cilia in ciliopathy and cancer; describe the roles of E3 ubiquitin ligases and deubiquitinases in ciliogenesis, ciliopathy, and cancer; and highlight some of the E3 ubiquitin ligases and deubiquitinases that are potential therapeutic targets for these disorders.
\end{abstract}

Keywords: ubiquitin-proteasome pathway; cilia; ciliogenesis; differentiation; proliferation; ciliopathy; cancer

\section{Introduction}

Cilia are antenna-like structures that are present in a variety of vertebrate cells [1-6]. There are two broad classes of cilia: Motile and nonmotile cilia [1]. The nonmotile cilia are called primary cilia. Both motile and primary cilia contain receptors and channels that detect signals from extracellular cues, such as mechanical flow and chemical stimulation, and transduce them into the cell, where they contribute to the maintenance of proper development and homeostasis. Considering these functions, it is not surprising that dysregulation of cilia function can cause cancer and other diseases, including ciliopathies, which manifest as various disease phenotypes, such as congenital anomalies, neurodevelopmental disorders, and obesity [1,6-9].

The structure and function of cilia are dynamically and precisely regulated, enabling cells to proliferate, migrate, and differentiate in a spatiotemporally controlled manner [6,10]. The primary cilium is composed of three compartments: The basal body, the transition zone, and the axoneme [2]. The basal body is derived from the mother centriole. Both centrioles and basal body contain nine circularly arranged triplets of microtubules (A-, B-, and C-tubules). The axoneme consists of nine microtubule doublets projected from the A- and B-tubules of the basal body. A central pair of 
singlet microtubules is present $(+2)$ and absent $(+0)$ in motile and primary cilia, respectively [11-14]. Therefore, the axoneme of motile and primary cilia is described as $9 \times 2+2$ and $9 \times 2+0$, respectively. The transition zone is a short area located above the basal body characterized by Y-shaped fibers connecting the microtubule doublets to the ciliary membrane [15]. The structure of motile cilia is more complex [16]. The daughter centriole plays an important role in the formation of motile cilia [16,17].

Primary cilia are disassembled and assembled when cells enter mitosis and exit the cell cycle, respectively [18-20]. The formation of primary cilia starts with the binding of small cytoplasmic vesicles transported from the Golgi apparatus to the mother centriole and conversion from the mother centriole to the basal body. The basal body is then moved and anchored to the plasma membrane. Coiled-coil protein 110, a component of the inhibitory complex of ciliogenesis, is removed to initiate axoneme elongation $[21,22]$. The ciliary vesicle then fuses with the plasma membrane, and large amounts of tubulin are transported from the cytoplasm into the cilium to extend the axoneme [23]. Many signaling molecules are also transported from the cytoplasm into the cilium (anterograde) and from the cilium into the cytoplasm (retrograde) by kinesin and dynein, respectively, which are motor proteins that travel along the axoneme [24].

Various types of posttranslational modification, including phosphorylation, acetylation, and ubiquitination, are involved in the dynamic regulation of the structure and function of cilia $[2,4-6,25]$. Modification of proteins by attachment of ubiquitin, a highly conserved 76-amino-acid protein, is a critical step in targeting the selective degradation of proteins by proteasomes as part of the ubiquitin-proteasome system (UPS) [26]. Protein ubiquitination occurs in three steps. First, ubiquitin-activating enzymes (E1) bind to ubiquitin, which is expressed in all cell types; second, ubiquitin is transferred from E1 enzymes to ubiquitin-conjugating enzymes (E2); and finally, ubiquitin-ligating enzymes (E3) transfer the ubiquitin from E2 enzymes and ligate it to lysine residues on the target protein. To date, 2, approximately 40, and about 600 E1, E2, and E3 enzymes, respectively, have been identified in humans [26]. The selectivity of target protein ubiquitination is conferred by the combination of E2 and E3 enzymes. Protein ubiquitination is counteracted by deubiquitinase (DUB)-mediated removal of ubiquitin moieties from ubiquitinated proteins [27]. About 100 DUBs have been identified in humans. The balance between ubiquitination and deubiquitination of target proteins and their proteasomal degradation are tightly regulated processes, and dysregulation of the UPS has been detected in various disorders [28-30].

Several lines of evidence support a major role for the UPS in regulating the structure and function of cilia [4-6,31-35]. Here, we briefly review the role of cilia in phenotypes of ciliopathy and cancer. We then focus on the role of E3 ubiquitin ligases and DUBs in ciliogenesis, ciliopathy, and cancer, and suggest that these enzymes may serve as novel therapeutic targets for the development of treatments for these disorders.

\section{Roles of Cilia in Ciliopathy and Cancer}

Cilia play crucial roles in the development of vertebrates. In some cell types, cilia are present only transiently during a critical point in development [36], and the spatiotemporal dysregulation of cilia can therefore affect the development of many organ systems, including the central nervous, sensory, cardiovascular, digestive, metabolic, and skeletal systems $[8,14,37,38]$. These complex multisystem developmental disorders are collectively termed ciliopathies (Table 1 ). 
Table 1. The roles of cilia in ciliopathy phenotypes.

\begin{tabular}{|c|c|c|}
\hline Ciliopathy Phenotype & Role of Cilia in the Phenotype & References \\
\hline Intellectual disability & $\begin{array}{l}\text { Dysfunction of cilia in radial glial progenitors } \\
\text { impairs the proliferation, migration, and } \\
\text { differentiation, resulting in the disruption of cerebral } \\
\text { cortical development and intellectual disability. }\end{array}$ & {$[39,40]$} \\
\hline Retinal degeneration & $\begin{array}{l}\text { Mutation of genes related to the structure and } \\
\text { function of axoneme in photoreceptor cells impair } \\
\text { protein (e.g., rhodopsin) transport along the } \\
\text { axoneme, resulting in retinal degeneration }\end{array}$ & {$[41,42]$} \\
\hline Craniofacial malformation & $\begin{array}{l}\text { Dysfunction of cilia in cranial neural crest cells } \\
\text { impairs the epithelial-mesenchymal transition and } \\
\text { the formation of facial prominences, causing } \\
\text { craniofacial malformation such as cleft lip/palate }\end{array}$ & {$[43,44]$} \\
\hline Laterality disorders & $\begin{array}{l}\text { Dysfunction of cilia in ventral node fails to break } \\
\text { left-right symmetry, left or right-side morphogenesis, } \\
\text { causing laterality disorders, such as situs inversus } \\
\text { and heterotaxy. }\end{array}$ & {$[45,46]$} \\
\hline Cystic kidney disease & $\begin{array}{l}\text { Dysfunction of cilia in renal tubular cells fails to } \\
\text { detect fluid flow, increase } \mathrm{Ca}^{2+} \text { concentration, and } \\
\text { suppress protein kinase A, causing renal cystogenesis } \\
\text { through dysregulated proliferation, apoptosis, and } \\
\text { cell polarity. }\end{array}$ & {$[47,48]$} \\
\hline Obesity & $\begin{array}{l}\text { Dysfunction of cilia in hypothalamic neurons and } \\
\text { adipocyte progenitor cess fails to suppress appetite } \\
\text { and regulate appropriate differentiation to } \\
\text { adipocytes, respectively, causing obesity. }\end{array}$ & {$[49,50]$} \\
\hline Scoliosis & $\begin{array}{c}\text { Primary cilia of osteoblasts are abnormally elongated } \\
\text { and dysfunctional in mechanotransduction, which } \\
\text { may impair loading-induced bone adaptation and } \\
\text { cause scoliosis }\end{array}$ & {$[51,52]$} \\
\hline Respiratory distress & $\begin{array}{l}\text { Mutations of genes affecting dynein arm, radial } \\
\text { spoke, central apparatus or multiciliation impair the } \\
\text { structure and/or function of motile cilia of epithelial } \\
\text { cells lining most of the respiratory tract, resulting in } \\
\text { mucus obstruction and respiratory failure. }\end{array}$ & {$[53,54]$} \\
\hline Infertility & $\begin{array}{l}\text { Impairment of sperm tail, which has microtubule } \\
\text { arrangement similar to that of motile cilia, cause } \\
\text { sperm immotility and male infertility. Dysfunction of } \\
\text { motile and primary cilia at the reproductive tract also } \\
\text { causes both male and female infertility. }\end{array}$ & {$[55,56]$} \\
\hline
\end{tabular}

\subsection{Intellectual Disability}

Defects in cerebral cortical development can lead to intellectual disabilities through a number of mechanisms [57]. Cortical development occurs in several steps: (1) Polarized radial glial progenitor formation, (2) radial/glial progenitor and intermediate progenitor proliferation, (3) radial/glial-guided neuronal migration, and (4) post-migratory neuronal differentiation, such as outgrowth and fasciculation of axons and dendrites [39]. The primary cilia of these progenitor cells play important roles in cerebral cortical development [40]. In Joubert syndrome, Bardet-Biedl syndrome (BBS), and oro-facial-digital syndrome, pathogenic mutations in genes regulating primary cilia function in progenitors disrupt cerebral cortical development [39], which can lead to intellectual disability [38]. 


\subsection{Retinal Degeneration}

The neuronal cell bodies of the retina are precisely organized in three major laminae: The ganglion cell, inner nuclear, and outer nuclear layers [58]. These layers are connected by neuronal projections of the cells located in each layer. Photoreceptor cells located in the outer nuclear layer capture photons and transmit signals to the brain through the inner nuclear and ganglion cell layers. Photoreceptor cells are composed of an outer segment (OS), inner segment (IS), and transition zone (also known as the connecting cilium), which connects the OS and IS [41,42]. The axoneme arises from the basal body in the IS and extends to the OS through the transition zone. Photon sensing is mainly performed by opsin proteins in the OS. Because the OS lacks protein synthesis machinery, opsin and other proteins involved in photon sensing are transported from the IS to the transition zone to the OS along the axoneme. Genes causative for ciliopathies, including Joubert syndrome, BBS, oro-facial-digital syndrome, Usher syndrome, and Meckel syndrome, are frequently involved in maintaining the structure and function of axonemes in photoreceptor cells [59]. Therefore, causative gene mutations in these ciliopathies often impair protein transport along the axoneme, resulting in retinal degeneration, and, potentially, vision loss, as is the case in retinitis pigmentosa and Leber congenital amaurosis $[41,42,59]$.

\subsection{Craniofacial Malformation}

Fusion of distinct prominences, including the frontonasal, paired maxillary, and mandibular prominences, is crucial for proper craniofacial development [43]. Cranial neural crest cells (CNCCs) originate at the neural tube, undergo epithelial-mesenchymal transition, and migrate toward and proliferate in facial prominences [44]. The primary cilia of CNCCs play crucial roles in these steps through transduction of the Hedgehog and wingless-type MMTV integration site family (WNT) signaling pathways $[43,44,60]$. Gene mutations associated with ciliopathies affecting the function of primary cilia in CNCCs can lead to craniofacial malformations, such as cleft or lip palate, hyper/hypotelorism, micrognathia, and craniosynostosis $[43,44,61,62]$.

\subsection{Laterality Disorders}

Although the human body is externally symmetrical, the visceral organs are arranged asymmetrically in a stereotyped manner $[45,46,63]$. Motile cilia of pit cells and nonmotile cilia of crown cells in the ventral node of the mammalian embryo play crucial roles in regulating left-right asymmetry $[64,65]$. When the motile cilia of pit cells generate leftward flow, the nonmotile cilia of crown cells located at the left side of the pit cells sense the flow and secrete Nodal-Gdf1 heterodimers [66,67]. In turn, the heterodimers bind to receptors in lateral plate mesoderm-derived cells and increase the expression of Nodal, Lefty2, and Pitx2, leading to left-side morphogenesis [68-71]. Accordingly, the impairment of cilia in the ventral node can cause laterality disorders, such as situs inversus and heterotaxy $[45,46,72-75]$.

\subsection{Cystic Kidney Disease}

Cystic kidney disease is one of the main renal ciliopathies [36,76]. Renal tubular cells detect fluid flow through cilia. In these cells, fluid flow increases $\mathrm{Ca}^{2+}$ uptake through calcium channels, such as polycystin $2[77,78]$, and the consequent increase in the intracellular $\mathrm{Ca}^{2+}$ concentration inhibits adenylate cyclase 6 and suppresses cyclic adenosine monophosphate (cAMP) signaling. The dysfunction of cilia in renal tubular cells prevents the increase in the $\mathrm{Ca}^{2+}$ concentration and suppression of cAMP signaling in response to fluid flow, resulting in activation of protein kinase A [47,48]. In turn, protein kinase A activation increases fluid secretion through chloride channels and deregulates multiple cellular pathways, including proliferation, apoptosis, and the polarity of renal tubular cells, leading to renal cystogenesis [79]. 


\subsection{Obesity}

Dysregulation of primary cilia in the central nervous system and peripheral tissues is associated with obesity, which often accompanies ciliopathies, such as BBS and Alström syndrome $[49,50,80,81]$. Obesity results from an excessive calorie intake relative to energy expenditure. In response to food intake, leptin is secreted from adipocytes and binds to receptors located in the primary cilia of anorexigenic and orexigenic neurons in the hypothalamus, resulting in increased and decreased expression of the anorexigenic peptide pro-opiomelanocortin and the orexigenic peptide Agouti-related peptide, respectively [82-84]. Genes associated with BBS and Alström syndrome regulate primary cilia in these hypothalamic neurons, and mutation of these genes can lead to obesity by failing to suppress the appetite through primary cilia-mediated leptin signaling [50].

Another contributing factor in obesity is elevated adipogenesis, resulting in an increased abundance of adipocytes [85]. Primary cilia are present in differentiating preadipocytes and play critical roles in adipogenesis [86]. Impairment of primary cilia in preadipocytes' knockdown of BBS proteins (BBS10 and BBS12) stimulates adipogenesis by activation of the glycogen synthase kinase 3 pathway and nuclear accumulation of peroxisome proliferator-activated receptor $\gamma$ [86]. Knockdown of BBS12 in human mesenchymal stem cells also impairs ciliogenesis and enhances adipogenesis [87]. In contrast, knockdown of intraflagellar transport 88 in preadipocytes or mesenchymal stem cells inhibits adipogenesis by impairing the localization of insulin-like growth factor-1 receptors in primary cilia $[88,89]$. The precise mechanisms by which primary cilia regulate adipogenesis remain to be fully elucidated.

\subsection{Scoliosis}

Scoliosis is a skeletal dysfunction characterized by abnormal spine curvature. Scoliosis is associated with an impaired structure and function of cilia [51]. The primary cilium of osteocyte acts as a hub in a mechanotransduction pathway for loading-induced bone adaptation [52,90]. In general, short primary cilia of osteocytes are perpendicularly oriented to the long axis of bone [91]. In contrast, primary cilia of osteoblasts from idiopathic scoliosis (IS) patients are significantly longer than those of control samples [51]. The induction of osteogenic factors, including bone morphogenic protein 2 (BMP2) and cyclooxygenase 2 (COX2), are impaired in osteoblasts from the IS patients and osteoblasts with elongated primary cilia by lithium chloride treatment [51]. These findings suggest that elongated primary cilia in osteocytes may be dysfunctional in mechanotransduction and warrant further investigation to elucidate the molecular mechanisms of scoliosis.

\subsection{Respiratory Distress}

Respiratory distress, which is characterized by congestion, coughing, tachypnea, and hypoxia, is a cardinal feature of primary ciliary dyskinesia (PCD) [53]. Motile cilia of the epithelial cell lining of most of the upper and lower respiratory tracts are dysfunctional in PCD [54,92,93]. The dysfunction of motile cilia causes the impairment of mucociliary clearance and mucus obstruction, resulting in bronchiectasis and respiratory failure [53]. Most PCD follow an autosomal recessive inheritance. The mutations identified as being causative of PCD explain roughly $70 \%$ of the affected individuals [93]. These mutations impair the structure and/or function of motile cilia by affecting the dynein arm, radial spoke, central apparatus, or multiciliation [93]. However, the clinical phenotype of PCD is highly variable [53]. The relationship between the genotype and clinical phenotype remains to be fully elucidated.

\subsection{Infertility}

The sperm tail has microtubule arrangement $(9 \times 2+2)$, which is similar to that of motile cilia [55]. Therefore, infertility is frequently observed in males with PCD [54]. There are some differences, however, between the sperm tail and motile cilia, including cell type-specific axonemal proteins 
and accessory structures specific to the sperm tail, such as the mitochondrial sheath, fibrous sheath, and outer dense fibers [55]. Mutations in genes causative of PCD are not always associated with male infertility and vice versa [55]. The impairment of the sperm tail affects sperm motility. The impairment of motile and primary cilia also affects the function of the reproductive tract in both males and females $[54,56]$. Structural and functional studies of cilia associated with infertility constitute an important area in reproductive research $[55,56]$.

\subsection{Roles of Primary Cilia in Cancer}

Primary cilia in cultured mouse 3T3 fibroblasts and human retinal pigment epithelial (RPE1) cells can be disassembled and assembled by serum stimulation and deprivation, respectively $[18,19,94]$. Aurora A kinase (AURKA), one of the most important mitotic kinases for cell-cycle control [95], plays important roles in deciliation by serum stimulation [96,97]. AURKA is activated by serum stimulation through $\mathrm{Ca}^{2+} /$ calmodulin signaling, the non-canonical WNT pathway, and phosphatidylinositol signaling [97-100]. Serum stimulation also activates AURKA through the pathway involving epidermal growth factor receptor (EGFR), ubiquitin-specific peptidase 8 (USP8), and trichoplein (TCHP) (described in the next section) $[33,34,101]$. Activated AURKA phosphorylates itself and target proteins during G1 phase, which stimulates the disassembly of primary cilia [97]. Several proteins associated with AURKA and ciliogenesis have been identified, including histone deacetylase 6 [94] and nudE neurodevelopment protein 1 (NDE1) [102]. In response to serum stimulation, NDE1 localizes at the basal body and suppresses ciliogenesis by tethering dynein light chain 1 [103]. Under serum deprivation conditions, cyclin-dependent kinase 5 is activated and phosphorylates NDE1. Phosphorylated NDE1 is then recognized and ubiquitylated by the E3 ligase complex SCF ${ }^{\mathrm{FBXW7}}$, resulting in ciliogenesis $[104,105]$. Importantly, forced ciliation in cells growing under serum stimulation conditions can cause cell-cycle arrest $[33,34,101,102,106]$. These findings suggest that the primary cilium can act as a negative regulator of the cell cycle and may be a tumor suppressor organelle [3-6,9,107-109]. In fact, the suppression of primary cilia function is associated with tumorigenesis, cell proliferation, and metastasis in many cancers, including glioblastoma [110], esophageal cancer [111], colon cancer [112], cholangiocarcinoma [113,114], pancreatic ductal adenocarcinoma [115], clear cell renal carcinoma [116], prostate cancer [117], ovarian cancer [118,119], melanoma [120], and chondrosarcoma [121] (Table 2). However, primary cilia can promote tumor progression under certain conditions. In medulloblastoma and basal cell skin carcinoma caused by gain-of-function mutation of SMO, primary cilia convert the GLI transcription factors GLI2 and GLI3 to their activated forms, inducing their translocation to the nucleus, increased transcription of Hedgehog target genes, and promotion of cell proliferation [122,123]. In contrast, primary cilia of medulloblastoma and basal cell skin carcinoma caused by gain-of-function mutation of GLI2 increases the activity of GLI3 as a transcriptional repressor, resulting in suppression of the proliferation of these cancer cells $[122,123]$. Further work will thus be necessary to fully understand the context-dependent roles of primary cilia in cell proliferation. 
Table 2. The roles of primary cilia in cancer.

\begin{tabular}{|c|c|c|}
\hline Cancer Cell & The Role of PC in the Cancer & References \\
\hline Glioblastoma & $\begin{array}{c}\text { Inhibition of HDAC6 restores the loss of PC and } \\
\text { suppressed the proliferation }\end{array}$ & [110] \\
\hline $\begin{array}{l}\text { Esophageal squamous } \\
\text { cell carcinoma }\end{array}$ & $\begin{array}{l}\text { KD of PRDX1 restores the loss of PC and } \\
\text { suppressed the proliferation }\end{array}$ & [111] \\
\hline Colon cancer & $\begin{array}{l}\text { Knockout of TTLL3 causes the loss of PC and } \\
\text { promotes tumorigenesis in colon }\end{array}$ & [112] \\
\hline Cholangiocarcinoma & $\begin{array}{c}\text { The number of PC is frequently reduced. } \\
\text { Inhibition of HDAC6 restores the loss of PC and } \\
\text { suppressed the proliferation }\end{array}$ & {$[113,114]$} \\
\hline $\begin{array}{l}\text { Pancreatic ductal } \\
\text { adenocarcinoma }\end{array}$ & $\begin{array}{l}\text { Inhibition of HDAC2 in Panc1 induces } \\
\text { ciliogenesis and suppressed the proliferation }\end{array}$ & [115] \\
\hline Clear cell renal carcinoma & $\begin{array}{l}\text { PC is lost by inactivation of VHL } \\
\text { tumor suppressor }\end{array}$ & [116] \\
\hline Prostate cancer & $\begin{array}{l}\text { KD of TACC } 3 \text { restores the loss of PC and } \\
\text { suppressed the proliferation }\end{array}$ & [117] \\
\hline Epithelial ovarian cancer & $\begin{array}{c}\text { The number of PC is reduced, which is associated } \\
\text { with centrosomal localization of AURKA. KD of } \\
\text { AURKA restores the loss of PC and suppressed } \\
\text { the oncogenic hedgehog signaling }\end{array}$ & {$[118,119]$} \\
\hline Melanoma & $\begin{array}{c}\text { Deconstruction of PC is sufficient to drive } \\
\text { metastatic formation }\end{array}$ & [120] \\
\hline Chondrosarcoma & $\begin{array}{c}\text { Inhibition of HDAC6 restores the loss of PC and } \\
\text { suppressed the proliferation }\end{array}$ & [121] \\
\hline $\begin{array}{l}\text { Medulloblastoma, } \\
\text { basal cell carcinoma }\end{array}$ & - & - \\
\hline with GOF mutation of SMO & $\begin{array}{l}\text { PC increase transcriptional activator and } \\
\text { stimulate proliferation }\end{array}$ & {$[122,123]$} \\
\hline with GOF mutation of GLI2 & $\begin{array}{c}\text { PC increase transcriptional suppressor and } \\
\text { inhibit proliferation }\end{array}$ & {$[122,123]$} \\
\hline
\end{tabular}

\section{Roles of E3 Ubiquitin Ligases and DUBs in Ciliogenesis, Ciliopathy, and Cancer}

The structure and function of cilia are dynamically regulated by many ciliary proteins through posttranslational modification [2,4-6,25]. Ubiquitination and deubiquitination of ciliary proteins by E3 ubiquitin ligase and DUBs, respectively, are crucial for the dynamic regulation of cilia [4-6,31-34]. In this section, we briefly describe the role of E3 ubiquitin ligases and DUBs in ciliogenesis, ciliopathy, and cancer (Table 3). 
A

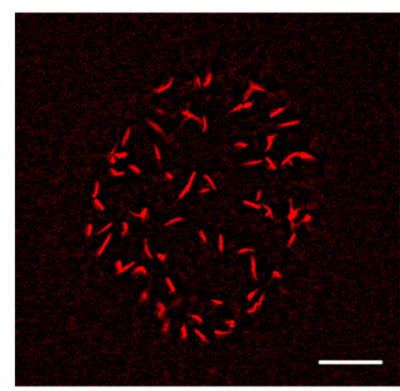

control

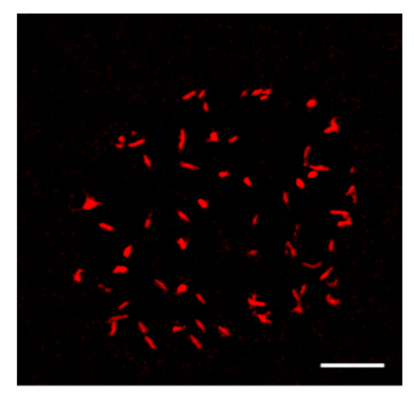

Kctd17 KO
C

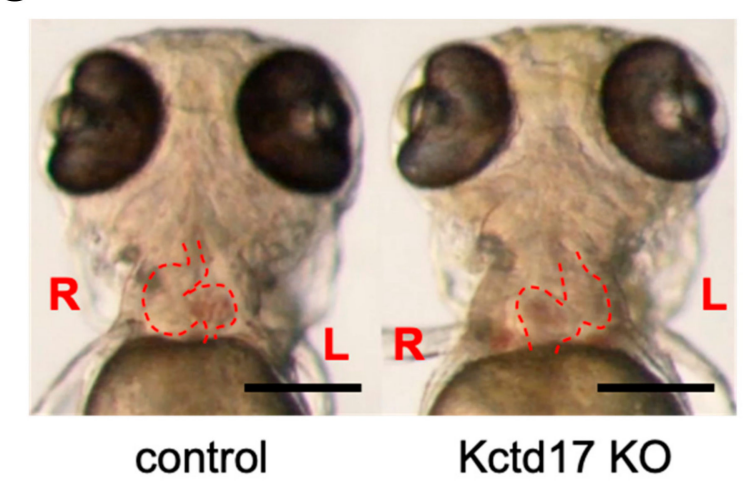

B
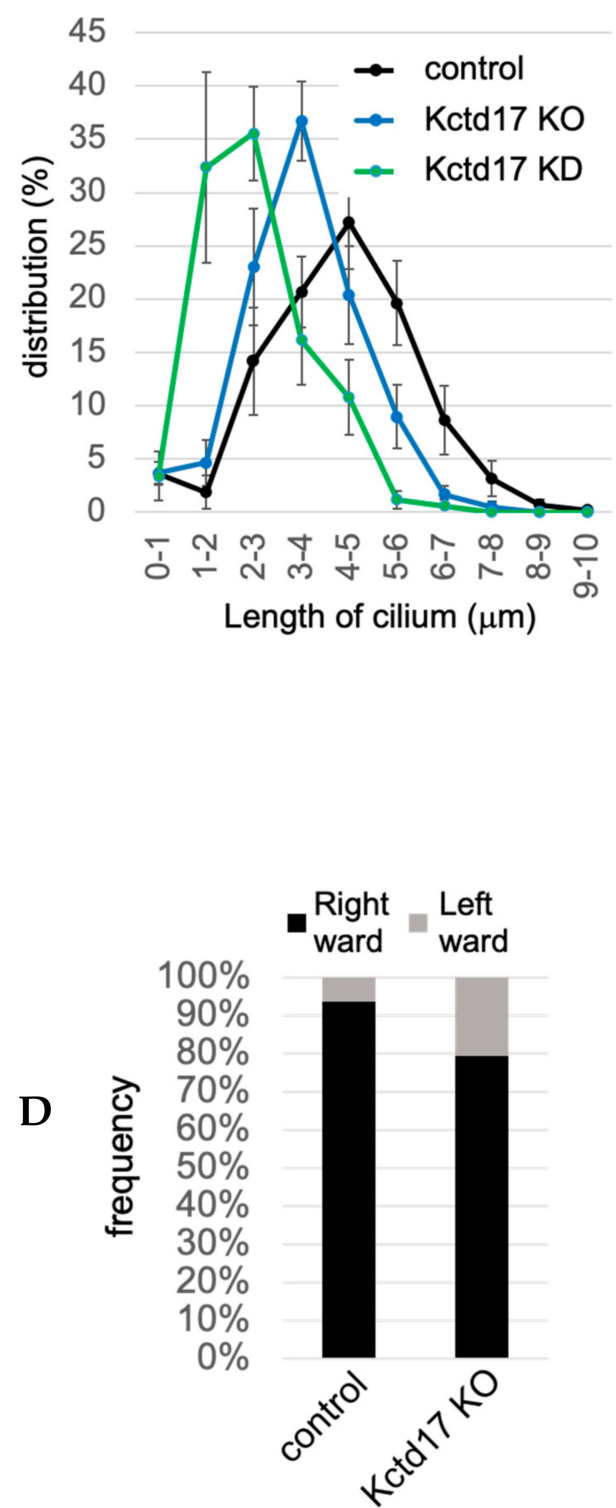

Figure 1. Suppression of Kctd17 in zebrafish impairs ciliogenesis in Kupffer's vesicle and induces situs inversus (A) Staining of acetylated alpha-tubulin in the cilia of Kupffer's vesicle at $12 \mathrm{~h}$ post-fertilization (hpf) of wild-type (control) or Kctd17 knockout (KO) zebrafish. (B) Distribution of the cilia length in Kupffer's vesicle at $12 \mathrm{hpf}$ in control or Kctd17 KO or knockdown (KD) zebrafish. (C) Representative in vivo images of control and Kctd17 KO zebrafish at 3 days post-fertilization (dpf). Control and Kctd17 KO zebrafish show rightward and leftward looping of the heart, respectively. Please see Video S1. (D) At $3 \mathrm{dpf}$, rightward and leftward looping of the heart is observed in about $95 \%$ of the control zebrafish and about $20 \%$ of the Kctd17 KO zebrafish, respectively. Scale bar: $20 \mu \mathrm{m}$ (A), $200 \mu \mathrm{m}$ (C). 
Table 3. The roles of E3 ubiquitin ligases and deubiquitinases in ciliogenesis, ciliopathy, and cancer.

\begin{tabular}{|c|c|c|c|}
\hline E3 Ligase or DUB & $\begin{array}{l}\text { The Role in Ciliogenesis } \\
\text { (Substrate) }\end{array}$ & $\begin{array}{l}\text { The Role in Ciliopathy and/or } \\
\text { Cancer }\end{array}$ & References \\
\hline CRL3-KCTD17 & $\begin{array}{l}\text { inhibited by KD of KCTD17 } \\
\text { (TCHP) }\end{array}$ & $\begin{array}{l}\text { KO of KCTD17 causes situs } \\
\text { inversus in zebrafish }\end{array}$ & [33], this paper (Figure 1 ) \\
\hline \multirow{3}{*}{ USP8 } & \multirow{3}{*}{$\begin{array}{l}\text { stimulated by KD of USP8 } \\
\text { (TCHP) }\end{array}$} & $\begin{array}{c}\text { KO of USP8 causes cystic kidney } \\
\text { in zebrafish }\end{array}$ & [34] \\
\hline & & $\begin{array}{l}\text { USP8 is highly expressed and } \\
\text { oncogenic in melanoma }\end{array}$ & [124] \\
\hline & & $\begin{array}{l}\text { Inhibition of USP8 suppresses } \\
\text { the proliferation of glioblastoma } \\
\text { stem cells }\end{array}$ & [125] \\
\hline MARCHF7 & $\begin{array}{l}\text { inhibited by OE of MARCHF7 } \\
\text { (IQCB1) }\end{array}$ & $\begin{array}{l}\text { MARCHF7 promotes } \\
\text { proliferation and invasion of } \\
\text { cervical cancer cells }\end{array}$ & {$[126,127]$} \\
\hline \multirow[b]{2}{*}{ TRIM32 } & \multirow[b]{2}{*}{$\begin{array}{l}\text { inhibited by OE of TRIM32 } \\
\text { (IQCB1) }\end{array}$} & $\begin{array}{l}\text { TRIM32 is a causative gene of } \\
\text { BBS (BBS11) }\end{array}$ & {$[126,127]$} \\
\hline & & $\begin{array}{l}\text { TRIM32 is oncogenic in head } \\
\text { and neck squamous cell } \\
\text { carcinoma and skin cancer }\end{array}$ & {$[128,129]$} \\
\hline \multirow[b]{2}{*}{ USP9X } & \multirow{2}{*}{$\begin{array}{l}\text { inhibited by KD of USP9X } \\
\text { (IQCB1) }\end{array}$} & $\begin{array}{l}\text { LOF mutations in USP9X cause } \\
\text { phenotypes related to ciliopathy }\end{array}$ & {$[126,130]$} \\
\hline & & $\begin{array}{l}\text { USP9X is a major tumor } \\
\text { suppressor gene in pancreatic } \\
\text { ductal adenocarcinoma }\end{array}$ & [131] \\
\hline \multirow[b]{2}{*}{ CYLD } & \multirow{2}{*}{$\begin{array}{l}\text { inhibited by KD/KO of CYLD } \\
\text { (CEP70, MIB1) }\end{array}$} & $\begin{array}{l}\mathrm{KO} / \mathrm{KD} \text { of CYLD causes } \\
\text { ciliopathy-related phenotype in } \\
\text { mouse and zebrafish }\end{array}$ & [132-134] \\
\hline & & $\begin{array}{l}\text { LOF mutation in CYLD cause } \\
\text { skin cancer (familial } \\
\text { cylindromatosis) }\end{array}$ & [135] \\
\hline MIB1 & $\begin{array}{l}\text { inhibited by OE of MIB1 } \\
\text { (PCM1, KIAA0586) }\end{array}$ & $\begin{array}{l}\text { MIB1 is oncogenic in upper } \\
\text { urinary-tract } \\
\text { urothelial carcinomas }\end{array}$ & {$[133,136,137]$} \\
\hline \multirow{2}{*}{ CRL2-VHL } & \multirow{2}{*}{$\begin{array}{l}\text { stimulated by OE of VHL } \\
\text { (HIF1A) }\end{array}$} & KO of VHL causes cystic kidney & {$[138,139]$} \\
\hline & & $\begin{array}{l}\text { VHL is tumor-suppressive in } \\
\text { renal cancers }\end{array}$ & [140] \\
\hline
\end{tabular}

DUBs—deubiquitinases; KD—knockdown; KO—knockout; OE—overexpression; LOF-loss-of-function.

\section{1. $C R L 3^{K C T D 17}, U S P 8$, and TCHP}

TCHP, a centriolar protein originally identified as a keratin-binding protein, activates AURKA and suppresses ciliogenesis $[101,141,142]$. TCHP is ubiquitinated by the E3 ligase CRL3 ${ }^{\text {KCTD17 }}$, a complex of the scaffold protein Cullin 3, RING box protein 1 (RBX1), and potassium channel tetramerization domain-containing 17 (KCTD17) [33]. Knockdown of KCTD17 in RPE1 cells suppresses ciliogenesis by stabilizing TCHP, leading to the activation of AURKA [33]. NDE1-like 1 (NDEL1), a modulator of dynein activity localized at the subdistal appendage of the mother centriole $[143,144]$, indirectly inhibits ubiquitination of TCHP by CRL3 ${ }^{\text {KCTD17 }}$ [106]. In contrast, TCHP is deubiquitinated by USP8 after EGFR-mediated phosphorylation of USP8 at tyrosine residues 717 and 810 [34]. Knockdown of USP8 in RPE1 cells induces ciliogenesis and cell-cycle arrest even in the presence of serum [34]. These findings suggest that forced ciliogenesis by inhibition of USP8 may be a potential therapeutic strategy for cancers with a high expression of USP8 and loss of cilia. In fact, USP8 is highly expressed and plays an oncogenic role in melanoma [124], and inhibition of USP8 suppresses the proliferation of glioblastoma stem cells [125]. The precise effect of USP8 on ciliogenesis in these tumor cells remains to be elucidated. In zebrafish, knockout of Usp8 increases ciliogenesis in renal tubules and causes renal cysts [34], whereas knockout of Kctd17 impairs ciliogenesis in Kupffer's vesicle and causes 
situs inversus (Figure 1). Because AURKA is also associated with both cancer and ciliopathy [95,97], these findings suggest that the involvement of KCTD17 and USP8 in cancer and ciliopathy might be mediated by effects on ciliogenesis via a TCHP-AURKA pathway.

\subsection{MARCHF7, TRIM32, USP9X, and IQCB1}

The IQ motif containing B1 (IQCB1), also known as Nephrocystin-5, increases ciliogenesis by binding to centrosomal protein 290 (CEP290) [145]. IQCB1 is ubiquitinated by membrane-associated ring-CH-type finger 7 (MARCHF7) and the tripartite motif containing 32 (TRIM32, also known as BBS11) [126]. Overexpression of MARCHF7 or TRIM32 inhibits ciliogenesis [126]. MARCHF7 promotes proliferation and invasion of cervical cancer cells [127], and TRIM32 is also oncogenic in head and neck squamous cell carcinoma and skin cancer $[128,129]$. Conversely, IQCB1 is deubiquitinated and stabilized by USP9X [126]. Knockdown of USP9X inhibits ciliogenesis [126]. USP9X is a major tumor suppressor gene in pancreatic ductal adenocarcinoma [131]. These findings suggest that MARCHF7, TRIM32, and USP9X may be involved in cancer via the modulation of ciliogenesis. Mutation of TRIM32, USP9X, and their substrate IQCB1 causes various phenotypes related to ciliopathy $[130,146,147]$.

\subsection{CYLD and MIB1}

Cylindromatosis (CYLD) is a member of the USP family of proteins and is expressed in centriolar satellites [148]. CYLD stimulates ciliogenesis by stabilizing centrosomal protein 70 (CEP70) and pericentriolar material 1 (PCM1) [132,133]. Stabilization of PCM1 by CYLD is mediated by deubiquitination of mindbomb E3 ubiquitin protein ligase 1 (MIB1), which is activated by ubiquitination on lysine 63 [133]. Lysine 63-ubiquitinated MIB1 then ubiquitinates PCM1 and stimulates its degradation in proteasomes. CYLD antagonizes the degradation of PCM1 by suppressing the activity of MIB1. MIB1 also ubiquitinates KIAA0586, a centrosomal protein also known as Talpid3, thereby stimulating its degradation and inhibiting ciliogenesis [136]. These findings suggest that CYLD and MIB1 positively and negatively, respectively, regulate ciliogenesis. Loss-of-function mutations in CYLD are associated with familial cylindromatosis, a condition involving multiple skin tumors [135]. MIB1 is oncogenic in upper urinary tract urothelial carcinomas [137]. Knockout or knockdown of CYLD in mice and zebrafish show phenotypes related to ciliopathy [134,149]. PCM1 and KIAA0586, both substrates of MIB1, are also associated with ciliopathies $[149,150]$.

\section{4. $C R L 2^{V H L}$}

The tumor suppressor protein von Hippel-Lindau (VHL) is a component of an E3 ubiquitin ligase complex that also contains the scaffold protein Cullin 2 and RBX1 [151]. Mutations in VHL related to formation of the E3 ubiquitin ligase complex lead to von Hippel-Lindau syndrome, which can exhibit both ciliopathy and cancer phenotypes [140,152]. CRL2 ${ }^{\mathrm{VHL}}$ ubiquitinates the $\alpha$ subunit of the transcription factor hypoxia-inducible factor 1 (HIF1 $\alpha)$, leading to its proteasomal degradation $[138,153]$. VHL and HIF1 $\alpha$ positively and negatively, respectively, regulate ciliogenesis and cancer $[107,139,140,154]$.

\section{Future Directions}

\subsection{Identification of E3 Ubiquitin Ligases and DUBs Related to Cilia Assembly and Disassembly}

As summarized above, the UPS has been implicated as a key system for the regulation of cilia assembly and disassembly $[32,33,155]$. Many E3 ubiquitin ligases and DUBs other than those listed in Table 3 have been identified as regulators of cilia assembly and disassembly. These include the E3 ubiquitin ligases cyclin F [156], FBW7 [104], NEDD4L [157], MYCBP2 [157], and UBR5 [158]; and the DUBs USP14 [159] and USP33 [160]; however, other enzymes undoubtedly remain to be identified. We showed that NDEL1, a modulator of dynein activity [143,144], inhibits ubiquitination of TCHP by CRL3 ${ }^{\text {KCTD17 }}$ and suppresses ciliogenesis in RPE1 cells incubated in the presence of serum [106]. 
Furthermore, in the absence of serum, NDEL1 is degraded by the UPS, resulting in the disappearance of TCHP from the mother centriole and induction of ciliogenesis [106]. The proteins involved in UPS-mediated NDEL1 degradation remain unknown.

One efficient approach to identifying E3 ubiquitin ligases of a substrate of interest is two-stepped global E3 screening, in which a wheat germ cell-free expression system is used to produce more than 1000 E3 ubiquitin ligases in the first step, and the enzymes are then screened using specific small interfering RNAs in the second step [33]. Genome-wide RNAi screening and proteomic profiling approaches may identify novel UPS proteins regulating cilia assembly and disassembly $[157,161,162]$. It will also be important to elucidate the subcellular compartment (basal body, transition zone, and/or axoneme) in which these E3 ubiquitin ligases and DUBs are active [32]. Compartment-specific proteomic profiling could be an efficient strategy to address these questions $[163,164]$.

\subsection{Identification of E3 Ubiquitin Ligase and DUB Substrates}

Although many E3 ubiquitin ligases and DUBs involved in the assembly and disassembly of cilia have been identified, the precise substrates of many of them remain unknown. For example, we performed RNAi screening of RPE1 cells and identified six DUBs, USP8, USP38, USP43, USP52, USP54, and UCHL3, as suppressors of ciliogenesis [34]. We also identified TCHP as a substrate of USP8 in the regulation of ciliogenesis [34], but the substrates for the other five DUBs are unknown. A variety of experimental approaches have been developed to identify DUB substrates [165]. Stable overexpression or knockdown of DUBs followed by quantitative proteomic analysis to detect proteins differentially expressed in control and manipulated cells identified Sec28p and NFX1-123 as substrates of Ubp3p and USP9X, respectively $[166,167]$. Affinity purification proteomics using tagged DUBs has identified CEP192 as a substrate of CYLD [168]. Similarly, affinity purification proteomics using antibodies that recognize the diglycine residues, a remnant present on the $\varepsilon$-amine of lysine following trypsin digestion of ubiquitinated proteins, was successful in identifying S100A6 and hnRNP K as SseL substrates [169]. The diglycine remnant affinity purification method can also be used to identify E3 ubiquitin ligase substrates $[170,171]$.

Once ligated to its substrate, ubiquitin itself can be modified by ubiquitination of one or more of its seven lysine residues (K6, K11, K27, K29, K33, K48, and K63) or the N-terminal methionine [172]. Polyubiquitination can be homotypic (same linkage) or heterotypic (different linkage) [173] and it plays various roles in cell signaling regulation depending on the linkage type [173]. For example, homotypic K48 polyubiquitination is related to classical proteasomal degradation; homotypic K63 polyubiquitination regulates protein-protein interactions; homotypic K6 and K27 polyubiquitinations are involved in the DNA damage response; and homotypic K29 and K33 polyubiquitinations are linked to innate immunity. In centriolar satellites, which are electron-dense and spherical cytoplasmic granules around centrosomes, modification of the E3 ubiquitin ligase MIB1 by homotypic K63 polyubiquitination induces homotypic K48 polyubiquitination of its substrate PCM1, resulting in PCM1 proteasomal degradation [133]. PCM1 plays an indispensable role in the clustering of centriolar satellites around the centrosome to orchestrate ciliogenesis [174]. CYLD located in centriolar satellites deubiquitinates the K63 polyubiquitin chain of MIB1, thereby antagonizing MIB1-mediated degradation of PCM1 and suppressing ciliogenesis [133]. Somatostatin receptor 3 (SSTR3) and G protein-coupled receptor 161 (GPR161) are important G protein-coupled receptors (GPCRs) that regulate somatostatin and hedgehog signaling, respectively, in primary cilia. K63 polyubiquitination of these GPCRs enables them to be recognized by ciliary exit machinery [175]. $\beta$-arrestin is known to mediate the K63 polyubiquitination of SSTR3 and GPR161, but the identity of the E3 ubiquitin ligase(s) involved is unclear. One important task for the future is the development of novel tools that will enable the identification of all E3 ubiquitin ligase and DUB substrates, as well as their ubiquitination patterns, related to the assembly and disassembly of cilia $[172,173,176]$. 


\subsection{Identification of Drugs Targeting E3 Ubiquitin Ligases and DUBs}

The screening of compounds for effects on protein ubiquitination and deubiquitination has led to the identification of a number of E3 ubiquitin ligase- and DUB-targeting drugs $[29,165,177]$. Because the substrates of these enzymes have a wide variety of functions, such drugs can interfere with various signaling pathways and impair physiological functions. Targeting the interaction of E3 ubiquitin ligases, DUBs, and their substrates involved in cilia assembly and disassembly may be a fruitful approach to developing selective drugs for the treatment of cancer and ciliopathies. Several technological advances have accelerated the development of drugs targeting protein-protein interactions [178,179]. The F-box protein S-phase kinase-associated protein 2 (SKP2), a component of E3 ubiquitin ligase SCF ${ }^{\mathrm{SK} P 2}$, ubiquitinates several proteins important for cell proliferation and survival, including p27 $7^{\mathrm{KIP} 1}$, p2 ${ }^{\mathrm{CIP} 1}$, and AKT serine/threonine kinases [180]. Some compounds have been identified that bind to a pocket in SKP2 that acts as the binding site for cyclin-dependent kinases regulatory subunit (CKS1), an accessory protein that can bind to $\mathrm{p} 27^{\mathrm{KIP} 1}$ phosphorylated by cyclin-dependent kinase 2/cyclin E [181-183]. These chemicals inhibit the interaction between SKP2 and CKS1, resulting in selective inhibition of SKP2-mediated ubiquitination and degradation of p27 ${ }^{\mathrm{KIP} 1}$. Screening for compounds that disrupt the subcellular translocation of E3 ubiquitin ligases and DUBs is another potential approach to developing selective drugs. USP4 and USP15 function in both the cytosol and the nucleus. In the cytosol, they deubiquitinate proteins involved in many signaling pathways, including those important to inflammation and oxidative stress; in the nucleus, they deubiquitinate proteins regulating splicing [184]. Nuclear translocation of these DUBs is inhibited by phosphorylation of two threonine residues located in the binding sites for spliceosome-associated factor 3 (SART3), a binding partner that facilitates the nuclear translocation of USP4 and USP15 [185]. Drugs interfering with the interaction between USP4 and USP15 and SART3 may selectively inhibit the DUB functions in the nucleus. Future work should include elucidation of the structure-activity relationships for E3 ubiquitin ligase- and/or DUB-targeting compounds and the identification of druggable sites in non-catalytic regions of the enzymes. Collectively, these approaches may lead to the development of novel drugs that regulate the enzymes in a context-dependent manner.

In summary, we have described the dysregulation of cilia in ciliopathies and cancers, and how that dysregulation results from changes in ciliary protein stability regulated by the UPS. As noted, some of the E3 ubiquitin ligases and DUBs involved in the maintenance of ciliary protein stability may be therapeutic targets for the associated disorders. Indeed, small molecules targeting these E3 ubiquitin ligases and DUBs, including USP8, USP9X, CYLD, and VHL, have been successfully developed $[29,177,186]$. However, the role of E3 ubiquitin ligases and DUBs in disease can be context dependent $[28,148,187,188]$. Thus, it will be important to develop small molecule modulators of the interactions between E3 ubiquitin ligases or DUBs and their binding proteins in a context-specific manner.

Supplementary Materials: Supplementary materials can be found at http://www.mdpi.com/1422-0067/21/17/ 5962/s1. Video S1: Representative movies of control and Kctd17 KO zebrafish at 3 dpf.

Funding: This work was supported in part by the Japan Society for the Promotion of Science KAKENHI (18K06890 to TS, $20 \mathrm{H} 03448$ to K.K., 20 K07356 to D.Y., 19 K07318 to Y.N.), Uehara Memorial Foundation (K.K.), and Takeda Science Foundation (K.K., Y.N., and M.I.).

Acknowledgments: We sincerely apologize to all researchers whose important work could not be cited because of space considerations. We thank Anne M. O'Rourke for editing a draft of this manuscript.

Conflicts of Interest: Research in the author's laboratories was conducted in the absence of any commercial or financial relationships that could be construed as a potential conflict of interest. 


\section{References}

1. Anvarian, Z.; Mykytyn, K.; Mukhopadhyay, S.; Pedersen, L.B.; Christensen, S.T. Cellular signalling by primary cilia in development, organ function and disease. Nat. Reviews. Nephrol. 2019, 15, $199-219$. [CrossRef] [PubMed]

2. Malicki, J.J.; Johnson, C.A. The Cilium: Cellular Antenna and Central Processing Unit. Trends Cell Biol. 2017, 27, 126-140. [CrossRef] [PubMed]

3. Goto, H.; Inoko, A.; Inagaki, M. Cell cycle progression by the repression of primary cilia formation in proliferating cells. Cell. Mol. Life Sci. 2013, 70, 3893-3905. [CrossRef] [PubMed]

4. Izawa, I.; Goto, H.; Kasahara, K.; Inagaki, M. Current topics of functional links between primary cilia and cell cycle. Cilia 2015, 4, 12. [CrossRef] [PubMed]

5. Goto, H.; Inaba, H.; Inagaki, M. Mechanisms of ciliogenesis suppression in dividing cells. Cell. Mol. Life Sci. 2017, 74, 881-890. [CrossRef] [PubMed]

6. Nishimura, Y.; Kasahara, K.; Shiromizu, T.; Watanabe, M.; Inagaki, M. Primary cilia as signaling hubs in health and disease. Adv. Sci. 2019, 6, 1801138. [CrossRef]

7. Valente, E.M.; Rosti, R.O.; Gibbs, E.; Gleeson, J.G. Primary cilia in neurodevelopmental disorders. Nat. Rev. Neurol. 2014, 10, 27-36. [CrossRef]

8. Reiter, J.F.; Leroux, M.R. Genes and molecular pathways underpinning ciliopathies. Nat. Rev. Mol. Cell Biol. 2017, 18, 533-547. [CrossRef]

9. Liu, H.; Kiseleva, A.A.; Golemis, E.A. Ciliary signalling in cancer. Nat. Rev. Cancer 2018, 18, 511-524. [CrossRef]

10. Wang, L.; Dynlacht, B.D. The regulation of cilium assembly and disassembly in development and disease. Development 2018, 145. [CrossRef]

11. Silverman, M.A.; Leroux, M.R. Intraflagellar transport and the generation of dynamic, structurally and functionally diverse cilia. Trends Cell Biol. 2009, 19, 306-316. [CrossRef] [PubMed]

12. Loreng, T.D.; Smith, E.F. The Central Apparatus of Cilia and Eukaryotic Flagella. Cold Spring Harb. Perspect Biol. 2017, 9. [CrossRef] [PubMed]

13. Ishikawa, T. Axoneme Structure from Motile Cilia. Cold Spring Harb. Perspect. Biol. 2017, 9. [CrossRef] [PubMed]

14. Mitchison, H.M.; Valente, E.M. Motile and non-motile cilia in human pathology: From function to phenotypes. J. Pathol. 2017, 241, 294-309. [CrossRef] [PubMed]

15. Reiter, J.F.; Blacque, O.E.; Leroux, M.R. The base of the cilium: Roles for transition fibres and the transition zone in ciliary formation, maintenance and compartmentalization. EMBO Rep. 2012, 13, 608-618. [CrossRef]

16. Alieva, I.; Staub, C.; Uzbekova, S.; Uzbekov, R. A question of flagella origin for spermatids-Mother or daughter centriole? In Flagella and Cilia Types, Strucure and Functions; Uzbekov, R.E., Ed.; Nova Science Publishers, Inc.: New York, NY, USA, 2018; pp. 109-126.

17. Al Jord, A.; Lemaître, A.I.; Delgehyr, N.; Faucourt, M.; Spassky, N.; Meunier, A. Centriole amplification by mother and daughter centrioles differs in multiciliated cells. Nature 2014, 516, 104-107. [CrossRef]

18. Tucker, R.W.; Pardee, A.B.; Fujiwara, K. Centriole ciliation is related to quiescence and DNA synthesis in 3T3 cells. Cell 1979, 17, 527-535. [CrossRef]

19. Tucker, R.W.; Scher, C.D.; Stiles, C.D. Centriole deciliation associated with the early response of 3 T3 cells to growth factors but not to SV40. Cell 1979, 18, 1065-1072. [CrossRef]

20. Rieder, C.L.; Jensen, C.G.; Jensen, L.C.W. The resorption of primary cilia during mitosis in a vertebrate (PtK1) cell line. J. Ultrastruct. Res. 1979, 68, 173-185. [CrossRef]

21. Tsang, W.Y.; Dynlacht, B.D. CP110 and its network of partners coordinately regulate cilia assembly. Cilia 2013, 2, 9. [CrossRef]

22. Yadav, S.P.; Sharma, N.K.; Liu, C.; Dong, L.; Li, T.; Swaroop, A. Centrosomal protein CP110 controls maturation of the mother centriole during cilia biogenesis. Developement 2016, 143, 1491-1501.

23. Craft, J.M.; Harris, J.A.; Hyman, S.; Kner, P.; Lechtreck, K.F. Tubulin transport by IFT is upregulated during ciliary growth by a cilium-autonomous mechanism. J. Cell Biol. 2015, 208, 223-237. [CrossRef] [PubMed]

24. Malicki, J.; Avidor-Reiss, T. From the cytoplasm into the cilium: Bon voyage. Organogenesis 2014, 10, $138-157$. [CrossRef] [PubMed] 
25. Mirvis, M.; Stearns, T.; James Nelson, W. Cilium structure, assembly, and disassembly regulated by the cytoskeleton. Biochem. J. 2018, 475, 2329-2353. [CrossRef]

26. Clague, M.J.; Heride, C.; Urbé, S. The demographics of the ubiquitin system. Trends Cell Biol. 2015, 25, 417-426. [CrossRef]

27. Leznicki, P.; Kulathu, Y. Mechanisms of regulation and diversification of deubiquitylating enzyme function. J. Cell Sci. 2017, 130, 1997-2006. [CrossRef]

28. Popovic, D.; Vucic, D.; Dikic, I. Ubiquitination in disease pathogenesis and treatment. Nat. Med. 2014, 20, 1242-1253. [CrossRef]

29. Harrigan, J.A.; Jacq, X.; Martin, N.M.; Jackson, S.P. Deubiquitylating enzymes and drug discovery: Emerging opportunities. Nat. Rev. Drug Discov. 2018, 17, 57-78. [CrossRef]

30. Senft, D.; Qi, J.; Ronai, Z.A. Ubiquitin ligases in oncogenic transformation and cancer therapy. Nat. Rev. Cancer 2018, 18, 69-88. [CrossRef]

31. Shearer, R.F.; Saunders, D.N. Regulation of primary cilia formation by the ubiquitin-proteasome system. Biochem. Soc. Trans. 2016, 44, 1265-1271. [CrossRef]

32. Hossain, D.; Tsang, W.Y. The role of ubiquitination in the regulation of primary cilia assembly and disassembly. Semin. Cell Dev. Biol. 2019, 93, 145-152. [CrossRef] [PubMed]

33. Kasahara, K.; Kawakami, Y.; Kiyono, T.; Yonemura, S.; Kawamura, Y.; Era, S.; Matsuzaki, F.; Goshima, N.; Inagaki, M. Ubiquitin-proteasome system controls ciliogenesis at the initial step of axoneme extension. Nat. Commun. 2014, 5, 5081. [CrossRef] [PubMed]

34. Kasahara, K.; Aoki, H.; Kiyono, T.; Wang, S.; Kagiwada, H.; Yuge, M.; Tanaka, T.; Nishimura, Y.; Mizoguchi, A.; Goshima, N.; et al. EGF receptor kinase suppresses ciliogenesis through activation of USP8 deubiquitinase. Nat. Commun. 2018, 9, 758. [CrossRef] [PubMed]

35. Toulis, V.; Marfany, G. By the Tips of Your Cilia: Ciliogenesis in the Retina and the Ubiquitin-Proteasome System. Adv. Exp. Med. Biol 2020, 1233, 303-310. [PubMed]

36. Pazour, G.J.; Quarmby, L.; Smith, A.O.; Desai, P.B.; Schmidts, M. Cilia in cystic kidney and other diseases. Cell Signal. 2020, 69, 109519. [CrossRef] [PubMed]

37. Hildebrandt, F.; Benzing, T.; Katsanis, N. Ciliopathies. N. Engl. J. Med. 2011, 364, 1533-1543. [CrossRef] [PubMed]

38. Braun, D.A.; Hildebrandt, F. Ciliopathies. Cold Spring Harb. Perspect. Biol. 2017, 9. [CrossRef] [PubMed]

39. Guo, J.; Higginbotham, H.; Li, J.; Nichols, J.; Hirt, J.; Ghukasyan, V.; Anton, E.S. Developmental disruptions underlying brain abnormalities in ciliopathies. Nat. Commun. 2015, 6, 7857. [CrossRef]

40. Youn, Y.H.; Han, Y.G. Primary Cilia in Brain Development and Diseases. Am. J. Pathol. 2018, 188, 11-22. [CrossRef]

41. Bujakowska, K.M.; Liu, Q.; Pierce, E.A. Photoreceptor Cilia and Retinal Ciliopathies. Cold Spring Harb. Perspect. Biol. 2017, 9. [CrossRef]

42. Bachmann-Gagescu, R.; Neuhauss, S.C. The photoreceptor cilium and its diseases. Curr. Opin. Genet. Dev. 2019, 56, 22-33. [CrossRef] [PubMed]

43. Schock, E.N.; Brugmann, S.A. Discovery, Diagnosis, and Etiology of Craniofacial Ciliopathies. Cold Spring Harb. Perspect. Biol. 2017, 9. [CrossRef]

44. Cortés, C.R.; Metzis, V.; Wicking, C. Unmasking the ciliopathies: Craniofacial defects and the primary cilium. Wiley Interdiscip. Rev. Dev. Biol. 2015, 4, 637-653. [CrossRef] [PubMed]

45. Dasgupta, A.; Amack, J.D. Cilia in vertebrate left-right patterning. Philos. Trans. R. Soc. Lond. B. Biol. Sci. 2016, 1710, 20150410. [CrossRef] [PubMed]

46. Grimes, D.T. Making and breaking symmetry in development, growth and disease. Development $2019,146$. [CrossRef]

47. Ye, H.; Wang, X.; Constans, M.M.; Sussman, C.R.; Chebib, F.T.; Irazabal, M.V.; Young, W.F., Jr.; Harris, P.C.; Kirschner, L.S.; Torres, V.E. The regulatory $1 \alpha$ subunit of protein kinase A modulates renal cystogenesis. Am. J. Physiol. Ren. Physiol. 2017, 313, 677-686. [CrossRef]

48. Cornec-Le Gall, E.; Alam, A.; Perrone, R.D. Autosomal dominant polycystic kidney disease. Lancet 2019, 393, 919-935. [CrossRef]

49. Mariman, E.C.; Vink, R.G.; Roumans, N.J.; Bouwman, F.G.; Stumpel, C.T.; Aller, E.E.; van Baak, M.A.; Wang, P. The cilium: A cellular antenna with an influence on obesity risk. Br. J. Nutr. 2016, 116, 576-592. [CrossRef] 
50. Engle, S.E.; Bansal, R.; Antonellis, P.J.; Berbari, N.F. Cilia signaling and obesity. Semin. Cell Dev. Biol. 2020. Available online: https://www.sciencedirect.com/science/article/abs/pii/S1084952119301831 (accessed on 19 August 2020).

51. Oliazadeh, N.; Gorman, K.F.; Eveleigh, R.; Bourque, G.; Moreau, A. Identification of Elongated Primary Cilia with Impaired Mechanotransduction in Idiopathic Scoliosis Patients. Sci. Rep. 2017, 7, 44260. [CrossRef]

52. Qin, L.; Liu, W.; Cao, H.; Xiao, G. Molecular mechanosensors in osteocytes. Bone Res. 2020, 8, 23. [CrossRef]

53. Sagel, S.D.; Davis, S.D.; Campisi, P.; Dell, S.D. Update of respiratory tract disease in children with primary ciliary dyskinesia. Proc. Am. Thorac. Soc. 2011, 8, 438-443. [CrossRef] [PubMed]

54. Mirra, V.; Werner, C.; Santamaria, F. Primary Ciliary Dyskinesia: An Update on Clinical Aspects, Genetics, Diagnosis, and Future Treatment Strategies. Front. Pediatr. 2017, 5, 135. [CrossRef] [PubMed]

55. Sironen, A.; Shoemark, A.; Patel, M.; Loebinger, M.R.; Mitchison, H.M. Sperm defects in primary ciliary dyskinesia and related causes of male infertility. Cell. Mol. Life Sci. 2020, 77, 2029-2048. [CrossRef] [PubMed]

56. Girardet, L.; Augière, C.; Asselin, M.-P.; Belleannée, C. Primary cilia: Biosensors of the male reproductive tract. Andrology 2019, 7, 588-602. [CrossRef] [PubMed]

57. Juric-Sekhar, G.; Hevner, R.F. Malformations of Cerebral Cortex Development: Molecules and Mechanisms. Annu. Rev. Pathol. 2019, 14, 293-318. [CrossRef] [PubMed]

58. Vecino, E.; Rodriguez, F.D.; Ruzafa, N.; Pereiro, X.; Sharma, S.C. Glia-neuron interactions in the mammalian retina. Prog. Retin. Eye Res. 2016, 51, 1-40. [CrossRef]

59. May-Simera, H.; Nagel-Wolfrum, K.; Wolfrum, U. Cilia-The sensory antennae in the eye. Prog. Retin. Eye Res. 2017, 60, 144-180. [CrossRef]

60. Jeong, J.; Mao, J.; Tenzen, T.; Kottmann, A.H.; McMahon, A.P. Hedgehog signaling in the neural crest cells regulates the patterning and growth of facial primordia. Genes Dev. 2004, 18, 937-951. [CrossRef]

61. Tobin, J.L.; Di Franco, M.; Eichers, E.; May-Simera, H.; Garcia, M.; Yan, J.; Quinlan, R.; Justice, M.J.; Hennekam, R.C.; Briscoe, J.; et al. Inhibition of neural crest migration underlies craniofacial dysmorphology and Hirschsprung's disease in Bardet-Biedl syndrome. Proc. Natl. Acad. Sci. USA 2008, 105, 6714-6719. [CrossRef]

62. Brugmann, S.A.; Allen, N.C.; James, A.W.; Mekonnen, Z.; Madan, E.; Helms, J.A. A primary cilia-dependent etiology for midline facial disorders. Hum. Mol. Genet. 2010, 19, 1577-1592. [CrossRef]

63. Hirokawa, N.; Tanaka, Y.; Okada, Y. Left-right determination: Involvement of molecular motor KIF3, cilia, and nodal flow. Cold Spring Harb. Perspect. Biol. 2009, 1, a000802. [CrossRef] [PubMed]

64. Kawasumi, A.; Nakamura, T.; Iwai, N.; Yashiro, K.; Saijoh, Y.; Belo, J.A.; Shiratori, H.; Hamada, H. Left-right asymmetry in the level of active Nodal protein produced in the node is translated into left-right asymmetry in the lateral plate of mouse embryos. Dev. Biol. 2011, 353, 321-330. [CrossRef] [PubMed]

65. Shiratori, H.; Hamada, H. TGFbeta signaling in establishing left-right asymmetry. Semin. Cell Dev. Biol. 2014, 32, 80-84. [CrossRef] [PubMed]

66. Marques, S.; Borges, A.C.; Silva, A.C.; Freitas, S.; Cordenonsi, M.; Belo, J.A. The activity of the Nodal antagonist Cerl-2 in the mouse node is required for correct L/R body axis. Genes Dev. 2004, 18, 2342-2347. [CrossRef]

67. Nakamura, T.; Saito, D.; Kawasumi, A.; Shinohara, K.; Asai, Y.; Takaoka, K.; Dong, F.; Takamatsu, A.; Belo, J.A.; Mochizuki, A.; et al. Fluid flow and interlinked feedback loops establish left-right asymmetric decay of Cerl2 mRNA. Nat. Commun. 2012, 3, 1322. [CrossRef]

68. Logan, M.; Pagan-Westphal, S.M.; Smith, D.M.; Paganessi, L.; Tabin, C.J. The transcription factor Pitx2 mediates situs-specific morphogenesis in response to left-right asymmetric signals. Cell 1998, 94, 307-317. [CrossRef]

69. Saijoh, Y.; Adachi, H.; Sakuma, R.; Yeo, C.Y.; Yashiro, K.; Watanabe, M.; Hashiguchi, H.; Mochida, K.; Ohishi, S.; Kawabata, M.; et al. Left-right asymmetric expression of lefty2 and nodal is induced by a signaling pathway that includes the transcription factor FAST2. Mol. Cell 2000, 5, 35-47. [CrossRef]

70. Shiratori, H.; Sakuma, R.; Watanabe, M.; Hashiguchi, H.; Mochida, K.; Sakai, Y.; Nishino, J.; Saijoh, Y.; Whitman, M.; Hamada, H. Two-step regulation of left-right asymmetric expression of Pitx2: Initiation by nodal signaling and maintenance by Nkx2. Mol. Cell 2001, 7, 137-149. [CrossRef]

71. Botilde, Y.; Yoshiba, S.; Shinohara, K.; Hasegawa, T.; Nishimura, H.; Shiratori, H.; Hamada, H. Cluap1 localizes preferentially to the base and tip of cilia and is required for ciliogenesis in the mouse embryo. Dev. Biol. 2013, 381, 203-212. [CrossRef] 
72. Ware, S.M.; Aygun, M.G.; Hildebrandt, F. Spectrum of clinical diseases caused by disorders of primary cilia. Proc. Am. Thorac. Soc. 2011, 8, 444-450. [CrossRef]

73. Oud, M.M.; Lamers, I.J.; Arts, H.H. Ciliopathies: Genetics in Pediatric Medicine. J. Pediatr. Genet. 2017, 6, 18-29. [CrossRef] [PubMed]

74. Matsui, T.; Bessho, Y. Left-right asymmetry in zebrafish. Cell. Mol. Life Sci. 2012, 69, 3069-3077. [CrossRef] [PubMed]

75. Matsui, T.; Ishikawa, H.; Bessho, Y. Cell collectivity regulation within migrating cell cluster during Kupffer's vesicle formation in zebrafish. Front. Cell Dev. Biol. 2015, 3, 27. [CrossRef] [PubMed]

76. Devlin, L.A.; Sayer, J.A. Renal ciliopathies. Curr. Opin. Genet. Dev. 2019, 56, 49-60. [CrossRef]

77. Mangolini, A.; de Stephanis, L.; Aguiari, G. Role of calcium in polycystic kidney disease: From signaling to pathology. World J. Nephrol 2016, 5, 76-83. [CrossRef]

78. Avasthi, P.; Maser, R.L.; Tran, P.V. Primary Cilia in Cystic Kidney Disease. Results Probl. Cell Differ. 2017, 60, 281-321.

79. Malekshahabi, T.; Khoshdel Rad, N.; Serra, A.L.; Moghadasali, R. Autosomal dominant polycystic kidney disease: Disrupted pathways and potential therapeutic interventions. J. Cell. Physiol. 2019, 234, 12451-12470. [CrossRef]

80. Oh, E.C.; Vasanth, S.; Katsanis, N. Metabolic regulation and energy homeostasis through the primary Cilium. Cell Metab. 2015, 21, 21-31. [CrossRef]

81. Vaisse, C.; Reiter, J.F.; Berbari, N.F. Cilia and Obesity. Cold Spring Harb. Perspect. Biol. 2017, 9, a028217. [CrossRef]

82. Ernst, M.B.; Wunderlich, C.M.; Hess, S.; Paehler, M.; Mesaros, A.; Koralov, S.B.; Kleinridders, A.; Husch, A.; Munzberg, H.; Hampel, B.; et al. Enhanced Stat3 activation in POMC neurons provokes negative feedback inhibition of leptin and insulin signaling in obesity. J. Neurosci. 2009, 29, 11582-11593. [CrossRef]

83. Mesaros, A.; Koralov, S.B.; Rother, E.; Wunderlich, F.T.; Ernst, M.B.; Barsh, G.S.; Rajewsky, K.; Bruning, J.C. Activation of Stat3 signaling in AgRP neurons promotes locomotor activity. Cell Metab. 2008, 7, 236-248. [CrossRef] [PubMed]

84. Han, Y.M.; Kang, G.M.; Byun, K.; Ko, H.W.; Kim, J.; Shin, M.S.; Kim, H.K.; Gil, S.Y.; Yu, J.H.; Lee, B.; et al. Leptin-promoted cilia assembly is critical for normal energy balance. J. Clin. Investig. 2014, 124, 2193-2197. [CrossRef]

85. Sebo, Z.L.; Rodeheffer, M.S. Assembling the adipose organ: Adipocyte lineage segregation and adipogenesis in vivo. Development 2019, 146. [CrossRef] [PubMed]

86. Marion, V.; Stoetzel, C.; Schlicht, D.; Messaddeq, N.; Koch, M.; Flori, E.; Danse, J.M.; Mandel, J.L.; Dollfus, H. Transient ciliogenesis involving Bardet-Biedl syndrome proteins is a fundamental characteristic of adipogenic differentiation. Proc. Natl. Acad. Sci. USA 2009, 106, 1820-1825. [CrossRef]

87. Marion, V.; Mockel, A.; De Melo, C.; Obringer, C.; Claussmann, A.; Simon, A.; Messaddeq, N.; Durand, M.; Dupuis, L.; Loeffler, J.P.; et al. BBS-induced ciliary defect enhances adipogenesis, causing paradoxical higher-insulin sensitivity, glucose usage, and decreased inflammatory response. Cell Metab. 2012, 16, $363-377$. [CrossRef] [PubMed]

88. Zhu, D.; Shi, S.; Wang, H.; Liao, K. Growth arrest induces primary-cilium formation and sensitizes IGF-1-receptor signaling during differentiation induction of 3T3-L1 preadipocytes. J. Cell Sci. 2009, 122, 2760-2768. [CrossRef]

89. Dalbay, M.T.; Thorpe, S.D.; Connelly, J.T.; Chapple, J.P.; Knight, M.M. Adipogenic Differentiation of hMSCs is Mediated by Recruitment of IGF-1r Onto the Primary Cilium Associated With Cilia Elongation. Stem Cells 2015, 33, 1952-1961. [CrossRef]

90. Spasic, M.; Jacobs, C.R. Primary cilia: Cell and molecular mechanosensors directing whole tissue function. Semin. Cell Dev. Biol. 2017, 71, 42-52. [CrossRef]

91. Uzbekov, R.E.; Maurel, D.B.; Aveline, P.C.; Pallu, S.; Benhamou, C.L.; Rochefort, G.Y. Centrosome fine ultrastructure of the osteocyte mechanosensitive primary cilium. Microsc. Microanal. 2012, 18, 1430-1441. [CrossRef] [PubMed]

92. Takeuchi, K.; Kitano, M.; Ishinaga, H.; Kobayashi, M.; Ogawa, S.; Nakatani, K.; Masuda, S.; Nagao, M.; Fujisawa, T. Recent advances in primary ciliary dyskinesia. Auris Nasus Larynx 2016, 43, 229-236. [CrossRef] [PubMed] 
93. Horani, A.; Ferkol, T.W.; Dutcher, S.K.; Brody, S.L. Genetics and biology of primary ciliary dyskinesia. Paediatr. Respir. Rev. 2016, 18, 18-24. [CrossRef] [PubMed]

94. Pugacheva, E.N.; Jablonski, S.A.; Hartman, T.R.; Henske, E.P.; Golemis, E.A. HEF1-dependent Aurora A activation induces disassembly of the primary cilium. Cell 2007, 129, 1351-1363. [CrossRef] [PubMed]

95. Otto, T.; Sicinski, P. Cell cycle proteins as promising targets in cancer therapy. Nat. Rev. Cancer 2017, 17, 93-115. [CrossRef] [PubMed]

96. Liang, Y.; Meng, D.; Zhu, B.; Pan, J. Mechanism of ciliary disassembly. Cell. Mol. Life Sci. 2016, 73, 1787-1802. [CrossRef] [PubMed]

97. Korobeynikov, V.; Deneka, A.Y.; Golemis, E.A. Mechanisms for nonmitotic activation of Aurora-A at cilia. Biochem. Soc. Trans. 2017, 45, 37-49. [CrossRef] [PubMed]

98. Plotnikova, O.V.; Nikonova, A.S.; Loskutov, Y.V.; Kozyulina, P.Y.; Pugacheva, E.N.; Golemis, E.A. Calmodulin activation of Aurora-A kinase (AURKA) is required during ciliary disassembly and in mitosis. Mol. Biol. Cell 2012, 23, 2658-2670. [CrossRef]

99. Lee, K.H.; Johmura, Y.; Yu, L.R.; Park, J.E.; Gao, Y.; Bang, J.K.; Zhou, M.; Veenstra, T.D.; Yeon Kim, B.; Lee, K.S. Identification of a novel Wnt5a-CK1varepsilon-Dvl2-Plk1-mediated primary cilia disassembly pathway. EMBO J. 2012, 31, 3104-3117. [CrossRef]

100. Plotnikova, O.V.; Seo, S.; Cottle, D.L.; Conduit, S.; Hakim, S.; Dyson, J.M.; Mitchell, C.A.; Smyth, I.M. INPP5E interacts with AURKA, linking phosphoinositide signaling to primary cilium stability. J. Cell Sci. 2015, 128, 364-372. [CrossRef]

101. Inoko, A.; Matsuyama, M.; Goto, H.; Ohmuro-Matsuyama, Y.; Hayashi, Y.; Enomoto, M.; Ibi, M.; Urano, T.; Yonemura, S.; Kiyono, T.; et al. Trichoplein and Aurora A block aberrant primary cilia assembly in proliferating cells. J. Cell Biol. 2012, 197, 391-405. [CrossRef]

102. Gabriel, E.; Wason, A.; Ramani, A.; Gooi, L.M.; Keller, P.; Pozniakovsky, A.; Poser, I.; Noack, F.; Telugu, N.S.; Calegari, F.; et al. CPAP promotes timely cilium disassembly to maintain neural progenitor pool. EMBO J. 2016, 35, 803-819. [CrossRef]

103. Pazour, G.J.; Wilkerson, C.G.; Witman, G.B. A dynein light chain is essential for the retrograde particle movement of intraflagellar transport (IFT). J. Cell Biol. 1998, 141, 979-992. [CrossRef] [PubMed]

104. Maskey, D.; Marlin, M.C.; Kim, S.; Kim, S.; Ong, E.C.; Li, G.; Tsiokas, L. Cell cycle-dependent ubiquitylation and destruction of NDE1 by CDK5-FBW7 regulates ciliary length. EMBO J. 2015, 34, 2424-2440. [CrossRef] [PubMed]

105. Nikonova, A.S.; Golemis, E.A. The tumor suppressor FBW7 controls ciliary length. EMBO J. 2015, 34, 2388-2390. [CrossRef] [PubMed]

106. Inaba, H.; Goto, H.; Kasahara, K.; Kumamoto, K.; Yonemura, S.; Inoko, A.; Yamano, S.; Wanibuchi, H.; He, D.; Goshima, N.; et al. Ndel1 suppresses ciliogenesis in proliferating cells by regulating the trichoplein-Aurora A pathway. J. Cell Biol. 2016, 212, 409-423. [CrossRef]

107. Fabbri, L.; Bost, F.; Mazure, N.M. Primary Cilium in Cancer Hallmarks. Int. J. Mol. Sci. 2019, $20,1336$. [CrossRef]

108. Higgins, M.; Obaidi, I.; McMorrow, T. Primary cilia and their role in cancer. Oncol. Lett. 2019, 17, 3041-3047. [CrossRef]

109. Peixoto, E.; Richard, S.; Pant, K.; Biswas, A.; Gradilone, S.A. The primary cilium: Its role as a tumor suppressor organelle. Biochem. Pharm. 2020, 175, 113906. [CrossRef] [PubMed]

110. Urdiciain, A.; Erausquin, E.; Meléndez, B.; Rey, J.A.; Idoate, M.A.; Castresana, J.S. Tubastatin A, an inhibitor of HDAC6, enhances temozolomide-induced apoptosis and reverses the malignant phenotype of glioblastoma cells. Int. J. Oncol. 2019, 54, 1797-1808. [CrossRef]

111. Chen, Q.; Li, J.; Yang, X.; Ma, J.; Gong, F.; Liu, Y. Prdx1 promotes the loss of primary cilia in esophageal squamous cell carcinoma. BMC Cancer 2020, 20, 372. [CrossRef]

112. Rocha, C.; Papon, L.; Cacheux, W.; Marques Sousa, P.; Lascano, V.; Tort, O.; Giordano, T.; Vacher, S.; Lemmers, B.; Mariani, P.; et al. Tubulin glycylases are required for primary cilia, control of cell proliferation and tumor development in colon. EMBO J. 2014, 33, 2247-2260. [CrossRef]

113. Gradilone, S.A.; Radtke, B.N.; Bogert, P.S.; Huang, B.Q.; Gajdos, G.B.; LaRusso, N.F. HDAC6 inhibition restores ciliary expression and decreases tumor growth. Cancer Res. 2013, 73, 2259-2270. [CrossRef] [PubMed] 
114. Mansini, A.P.; Peixoto, E.; Thelen, K.M.; Gaspari, C.; Jin, S.; Gradilone, S.A. The cholangiocyte primary cilium in health and disease. Biochim. Biophys. Acta 2018, 1864, 1245-1253. [CrossRef] [PubMed]

115. Kobayashi, T.; Nakazono, K.; Tokuda, M.; Mashima, Y.; Dynlacht, B.D.; Itoh, H. HDAC2 promotes loss of primary cilia in pancreatic ductal adenocarcinoma. EMBO Rep. 2017, 18, 334-343. [CrossRef] [PubMed]

116. Esteban, M.A.; Harten, S.K.; Tran, M.G.; Maxwell, P.H. Formation of primary cilia in the renal epithelium is regulated by the von Hippel-Lindau tumor suppressor protein. J. Am. Soc. Nephrol. 2006, 17, 1801-1806. [CrossRef]

117. Qie, Y.; Wang, L.; Du, E.; Chen, S.; Lu, C.; Ding, N.; Yang, K.; Xu, Y. TACC3 promotes prostate cancer cell proliferation and restrains primary cilium formation. Exp. Cell Res. 2020, 390, 111952. [CrossRef]

118. Bhattacharya, R.; Kwon, J.; Ali, B.; Wang, E.; Patra, S.; Shridhar, V.; Mukherjee, P. Role of hedgehog signaling in ovarian cancer. Clin. Cancer Res. 2008, 14, 7659-7666. [CrossRef]

119. Egeberg, D.L.; Lethan, M.; Manguso, R.; Schneider, L.; Awan, A.; Jorgensen, T.S.; Byskov, A.G.; Pedersen, L.B.; Christensen, S.T. Primary cilia and aberrant cell signaling in epithelial ovarian cancer. Cilia 2012, 1, 15. [CrossRef]

120. Zingg, D.; Debbache, J.; Peña-Hernández, R.; Antunes, A.T.; Schaefer, S.M.; Cheng, P.F.; Zimmerli, D.; Haeusel, J.; Calçada, R.R.; Tuncer, E.; et al. EZH2-Mediated Primary Cilium Deconstruction Drives Metastatic Melanoma Formation. Cancer Cell 2018, 34, 69-84. [CrossRef]

121. Xiang, W.; Guo, F.; Cheng, W.; Zhang, J.; Huang, J.; Wang, R.; Ma, Z.; Xu, K. HDAC6 inhibition suppresses chondrosarcoma by restoring the expression of primary cilia. Oncol. Rep. 2017, 38, 229-236. [CrossRef]

122. Wong, S.Y.; Seol, A.D.; So, P.L.; Ermilov, A.N.; Bichakjian, C.K.; Epstein, E.H., Jr.; Dlugosz, A.A.; Reiter, J.F. Primary cilia can both mediate and suppress Hedgehog pathway-dependent tumorigenesis. Nat. Med. 2009, 15, 1055-1061. [CrossRef]

123. Han, Y.G.; Kim, H.J.; Dlugosz, A.A.; Ellison, D.W.; Gilbertson, R.J.; Alvarez-Buylla, A. Dual and opposing roles of primary cilia in medulloblastoma development. Nat. Med. 2009, 15, 1062-1065. [CrossRef] [PubMed]

124. Jeong, M.; Lee, E.W.; Seong, D.; Seo, J.; Kim, J.H.; Grootjans, S.; Kim, S.Y.; Vandenabeele, P.; Song, J. USP8 suppresses death receptor-mediated apoptosis by enhancing FLIP(L) stability. Oncogene 2017, 36, 458-470. [CrossRef] [PubMed]

125. MacLeod, G.; Bozek, D.A.; Rajakulendran, N.; Monteiro, V.; Ahmadi, M.; Steinhart, Z.; Kushida, M.M.; Yu, H.; Coutinho, F.J.; Cavalli, F.M.G.; et al. Genome-Wide CRISPR-Cas9 Screens Expose Genetic Vulnerabilities and Mechanisms of Temozolomide Sensitivity in Glioblastoma Stem Cells. Cell Rep. 2019, 27, 971-986. [CrossRef] [PubMed]

126. Das, A.; Qian, J.; Tsang, W.Y. USP9X counteracts differential ubiquitination of NPHP5 by MARCH7 and BBS11 to regulate ciliogenesis. PLoS Genet. 2017, 13, e1006791. [CrossRef] [PubMed]

127. Hu, J.; Meng, Y.; Zeng, J.; Zeng, B.; Jiang, X. Ubiquitin E3 Ligase MARCH7 promotes proliferation and invasion of cervical cancer cells through VAV2-RAC1-CDC42 pathway. Oncol. Lett. 2018, 16, 2312-2318. [CrossRef] [PubMed]

128. Kano, S.; Miyajima, N.; Fukuda, S.; Hatakeyama, S. Tripartite motif protein 32 facilitates cell growth and migration via degradation of Abl-interactor 2. Cancer Res. 2008, 68, 5572-5580. [CrossRef]

129. Horn, E.J.; Albor, A.; Liu, Y.; El-Hizawi, S.; Vanderbeek, G.E.; Babcock, M.; Bowden, G.T.; Hennings, H.; Lozano, G.; Weinberg, W.C.; et al. RING protein Trim32 associated with skin carcinogenesis has anti-apoptotic and E3-ubiquitin ligase properties. Carcinogenesis 2004, 25, 157-167. [CrossRef]

130. Reijnders, M.R.; Zachariadis, V.; Latour, B.; Jolly, L.; Mancini, G.M.; Pfundt, R.; Wu, K.M.; van Ravenswaaij-Arts, C.M.; Veenstra-Knol, H.E.; Anderlid, B.M.; et al. De Novo Loss-of-Function Mutations in USP9X Cause a Female-Specific Recognizable Syndrome with Developmental Delay and Congenital Malformations. Am. J. Hum. Genet. 2016, 98, 373-381. [CrossRef]

131. Pérez-Mancera, P.A.; Rust, A.G.; van der Weyden, L.; Kristiansen, G.; Li, A.; Sarver, A.L.; Silverstein, K.A.T.; Grützmann, R.; Aust, D.; Rümmele, P.; et al. The deubiquitinase USP9X suppresses pancreatic ductal adenocarcinoma. Nature 2012, 486, 266-270. [CrossRef]

132. Yang, Y.; Ran, J.; Liu, M.; Li, D.; Li, Y.; Shi, X.; Meng, D.; Pan, J.; Ou, G.; Aneja, R.; et al. CYLD mediates ciliogenesis in multiple organs by deubiquitinating Cep70 and inactivating HDAC6. Cell Res. 2014, 24, 1342-1353. [CrossRef]

133. Douanne, T.; André-Grégoire, G.; Thys, A.; Trillet, K.; Gavard, J.; Bidère, N. CYLD Regulates Centriolar Satellites Proteostasis by Counteracting the E3 Ligase MIB1. Cell Rep. 2019, 27, 1657-1665. [CrossRef] 
134. Tse, W.K.F. Importance of deubiquitinases in zebrafish craniofacial development. Biochem. Biophys. Res. Commun. 2017, 487, 813-819. [CrossRef] [PubMed]

135. Bignell, G.R.; Warren, W.; Seal, S.; Takahashi, M.; Rapley, E.; Barfoot, R.; Green, H.; Brown, C.; Biggs, P.J.; Lakhani, S.R.; et al. Identification of the familial cylindromatosis tumour-suppressor gene. Nat. Genet. 2000, 25, 160-165. [CrossRef]

136. Wang, L.; Lee, K.; Malonis, R.; Sanchez, I.; Dynlacht, B.D. Tethering of an E3 ligase by PCM1 regulates the abundance of centrosomal KIAA0586/Talpid3 and promotes ciliogenesis. Elife 2016, 5, e12950. [CrossRef]

137. Lei, Y.; Li, Z.; Qi, L.; Tong, S.; Li, B.; He, W.; Chen, M. The Prognostic Role of Ki-67/MIB-1 in Upper Urinary-Tract Urothelial Carcinomas: A Systematic Review and Meta-Analysis. J. Endourol. 2015, 29, 1302-1308. [CrossRef]

138. Ang, S.O.; Chen, H.; Hirota, K.; Gordeuk, V.R.; Jelinek, J.; Guan, Y.; Liu, E.; Sergueeva, A.I.; Miasnikova, G.Y.; Mole, D.; et al. Disruption of oxygen homeostasis underlies congenital Chuvash polycythemia. Nat. Genet. 2002, 32, 614-621. [CrossRef] [PubMed]

139. Schermer, B.; Ghenoiu, C.; Bartram, M.; Müller, R.U.; Kotsis, F.; Höhne, M.; Kühn, W.; Rapka, M.; Nitschke, R.; Zentgraf, H.; et al. The von Hippel-Lindau tumor suppressor protein controls ciliogenesis by orienting microtubule growth. J. Cell Biol. 2006, 175, 547-554. [CrossRef] [PubMed]

140. Kaelin, W.G., Jr. The VHL Tumor Suppressor Gene: Insights into Oxygen Sensing and Cancer. Trans. Am. Clin. Clim. Assoc. 2017, 128, 298-307.

141. Nishizawa, M.; Izawa, I.; Inoko, A.; Hayashi, Y.; Nagata, K.; Yokoyama, T.; Usukura, J.; Inagaki, M. Identification of trichoplein, a novel keratin filament-binding protein. J. Cell Sci. 2005, 118, 1081-1090. [CrossRef] [PubMed]

142. Ibi, M.; Zou, P.; Inoko, A.; Shiromizu, T.; Matsuyama, M.; Hayashi, Y.; Enomoto, M.; Mori, D.; Hirotsune, S.; Kiyono, T;; et al. Trichoplein controls microtubule anchoring at the centrosome by binding to Odf2 and ninein. J. Cell Sci. 2011, 124, 857-864. [CrossRef]

143. Sasaki, S.; Shionoya, A.; Ishida, M.; Gambello, M.J.; Yingling, J.; Wynshaw-Boris, A.; Hirotsune, S. A LIS1/NUDEL/cytoplasmic dynein heavy chain complex in the developing and adult nervous system. Neuron 2000, 28, 681-696. [CrossRef]

144. Niethammer, M.; Smith, D.S.; Ayala, R.; Peng, J.; Ko, J.; Lee, M.S.; Morabito, M.; Tsai, L.H. NUDEL is a novel Cdk5 substrate that associates with LIS1 and cytoplasmic dynein. Neuron 2000, 28, 697-711. [CrossRef]

145. Barbelanne, M.; Song, J.; Ahmadzai, M.; Tsang, W.Y. Pathogenic NPHP5 mutations impair protein interaction with Cep290, a prerequisite for ciliogenesis. Hum. Mol. Genet. 2013, 22, 2482-2494. [CrossRef]

146. Chiang, A.P.; Beck, J.S.; Yen, H.J.; Tayeh, M.K.; Scheetz, T.E.; Swiderski, R.E.; Nishimura, D.Y.; Braun, T.A.; Kim, K.Y.; Huang, J.; et al. Homozygosity mapping with SNP arrays identifies TRIM32, an E3 ubiquitin ligase, as a Bardet-Biedl syndrome gene (BBS11). Proc. Natl. Acad. Sci. USA 2006, 103, 6287-6292. [CrossRef] [PubMed]

147. Otto, E.A.; Loeys, B.; Khanna, H.; Hellemans, J.; Sudbrak, R.; Fan, S.; Muerb, U.; O’Toole, J.F.; Helou, J.; Attanasio, M.; et al. Nephrocystin-5, a ciliary IQ domain protein, is mutated in Senior-Loken syndrome and interacts with RPGR and calmodulin. Nat. Genet. 2005, 37, 282-288. [CrossRef] [PubMed]

148. Yang, Y.; Zhou, J. CYLD—A deubiquitylase that acts to fine-tune microtubule properties and functions. J. Cell Sci. 2016, 129, 2289-2295. [CrossRef]

149. Farooqi, I.S. Genetic and hereditary aspects of childhood obesity. Best Pract. Res. Clin. Endocrinol. Metab. 2005, 19, 359-374. [CrossRef]

150. Stephen, L.A.; Tawamie, H.; Davis, G.M.; Tebbe, L.; Nürnberg, P.; Nürnberg, G.; Thiele, H.; Thoenes, M.; Boltshauser, E.; Uebe, S.; et al. TALPID3 controls centrosome and cell polarity and the human ortholog KIAA0586 is mutated in Joubert syndrome (JBTS23). Elife 2015, 4, e08077. [CrossRef]

151. Kamura, T.; Koepp, D.M.; Conrad, M.N.; Skowyra, D.; Moreland, R.J.; Iliopoulos, O.; Lane, W.S.; Kaelin, W.G., Jr.; Elledge, S.J.; Conaway, R.C.; et al. Rbx1, a component of the VHL tumor suppressor complex and SCF ubiquitin ligase. Science 1999, 284, 657-661. [CrossRef]

152. Kuehn, E.W.; Walz, G.; Benzing, T. Von hippel-lindau: A tumor suppressor links microtubules to ciliogenesis and cancer development. Cancer Res. 2007, 67, 4537-4540. [CrossRef]

153. Ohh, M.; Park, C.W.; Ivan, M.; Hoffman, M.A.; Kim, T.-Y.; Huang, L.E.; Pavletich, N.; Chau, V.; Kaelin, W.G. Ubiquitination of hypoxia-inducible factor requires direct binding to the $\beta$-domain of the von Hippel-Lindau protein. Nat. Cell Biol. 2000, 2, 423-427. [CrossRef] 
154. Hayashi, Y.; Yokota, A.; Harada, H.; Huang, G. Hypoxia/pseudohypoxia-mediated activation of hypoxia-inducible factor- $1 \alpha$ in cancer. Cancer Sci. 2019, 110, 1510-1517. [CrossRef] [PubMed]

155. Huang, K.; Diener, D.R.; Rosenbaum, J.L. The ubiquitin conjugation system is involved in the disassembly of cilia and flagella. J. Cell Biol. 2009, 186, 601-613. [CrossRef] [PubMed]

156. D'Angiolella, V.; Donato, V.; Vijayakumar, S.; Saraf, A.; Florens, L.; Washburn, M.P.; Dynlacht, B.; Pagano, M. SCF(Cyclin F) controls centrosome homeostasis and mitotic fidelity through CP110 degradation. Nature 2010, 466, 138-142. [CrossRef] [PubMed]

157. Mick, D.U.; Rodrigues, R.B.; Leib, R.D.; Adams, C.M.; Chien, A.S.; Gygi, S.P.; Nachury, M.V. Proteomics of Primary Cilia by Proximity Labeling. Dev. Cell 2015, 35, 497-512. [CrossRef] [PubMed]

158. Shearer, R.F.; Frikstad, K.M.; McKenna, J.; McCloy, R.A.; Deng, N.; Burgess, A.; Stokke, T.; Patzke, S.; Saunders, D.N. The E3 ubiquitin ligase UBR5 regulates centriolar satellite stability and primary cilia. Mol. Biol. Cell 2018, 29, 1542-1554. [CrossRef] [PubMed]

159. Massa, F.; Tammaro, R.; Prado, M.A.; Cesana, M.; Lee, B.H.; Finley, D.; Franco, B.; Morleo, M. The deubiquitinating enzyme Usp14 controls ciliogenesis and Hedgehog signaling. Hum. Mol. Genet. 2019, 28, 764-777. [CrossRef]

160. Li, J.; D’Angiolella, V.; Seeley, E.S.; Kim, S.; Kobayashi, T.; Fu, W.; Campos, E.I.; Pagano, M.; Dynlacht, B.D. USP33 regulates centrosome biogenesis via deubiquitination of the centriolar protein CP110. Nature 2013, 495, 255-259. [CrossRef]

161. Wheway, G.; Schmidts, M.; Mans, D.A.; Szymanska, K.; Nguyen, T.T.; Racher, H.; Phelps, I.G.; Toedt, G.; Kennedy, J.; Wunderlich, K.A.; et al. An siRNA-based functional genomics screen for the identification of regulators of ciliogenesis and ciliopathy genes. Nat. Cell Biol. 2015, 17, 1074-1087. [CrossRef]

162. Kim, J.H.; Ki, S.M.; Joung, J.G.; Scott, E.; Heynen-Genel, S.; Aza-Blanc, P.; Kwon, C.H.; Kim, J.; Gleeson, J.G.; Lee, J.E. Genome-wide screen identifies novel machineries required for both ciliogenesis and cell cycle arrest upon serum starvation. Biochim. Biophys. Acta 2016, 1863, 1307-1318. [CrossRef]

163. Kohli, P.; Höhne, M.; Jüngst, C.; Bertsch, S.; Ebert, L.K.; Schauss, A.C.; Benzing, T.; Rinschen, M.M.; Schermer, B. The ciliary membrane-associated proteome reveals actin-binding proteins as key components of cilia. EMBO Rep. 2017, 18, 1521-1535. [CrossRef] [PubMed]

164. Lundberg, E.; Borner, G.H.H. Spatial proteomics: A powerful discovery tool for cell biology. Nat. Rev. Mol. Cell Biol. 2019, 20, 285-302. [CrossRef] [PubMed]

165. Kliza, K.; Husnjak, K. Resolving the Complexity of Ubiquitin Networks. Front. Mol. Biosci. 2020, 7, 21. [CrossRef] [PubMed]

166. Poulsen, J.W.; Madsen, C.T.; Young, C.; Kelstrup, C.D.; Grell, H.C.; Henriksen, P.; Juhl-Jensen, L.; Nielsen, M.L. Comprehensive profiling of proteome changes upon sequential deletion of deubiquitylating enzymes. J. Proteom. 2012, 75, 3886-3897. [CrossRef] [PubMed]

167. Chen, X.; Lu, D.; Gao, J.; Zhu, H.; Zhou, Y.; Gao, D.; Zhou, H. Identification of a USP9X Substrate NFX1-123 by SILAC-Based Quantitative Proteomics. J. Proteome Res. 2019, 18, 2654-2665. [CrossRef] [PubMed]

168. Gomez-Ferreria, M.A.; Bashkurov, M.; Mullin, M.; Gingras, A.C.; Pelletier, L. CEP192 interacts physically and functionally with the K63-deubiquitinase CYLD to promote mitotic spindle assembly. Cell Cycle 2012, 11, 3555-3558. [CrossRef]

169. Nakayasu, E.S.; Sydor, M.A.; Brown, R.N.; Sontag, R.L.; Sobreira, T.J.P.; Slysz, G.W.; Humphrys, D.R.; Skarina, T.; Onoprienko, O.; Di Leo, R.; et al. Identification of Salmonella Typhimurium Deubiquitinase SseL Substrates by Immunoaffinity Enrichment and Quantitative Proteomic Analysis. J. Proteome Res. 2015, 14, 4029-4038. [CrossRef]

170. Iconomou, M.; Saunders, D.N. Systematic approaches to identify E3 ligase substrates. Biochem. J. 2016, 473, 4083-4101. [CrossRef]

171. O'Connor, H.F.; Huibregtse, J.M. Enzyme-substrate relationships in the ubiquitin system: Approaches for identifying substrates of ubiquitin ligases. Cell. Mol. Life Sci. 2017, 74, 3363-3375. [CrossRef]

172. Mattern, M.; Sutherland, J.; Kadimisetty, K.; Barrio, R.; Rodriguez, M.S. Using Ubiquitin Binders to Decipher the Ubiquitin Code. Trends Biochem. Sci. 2019, 44, 599-615. [CrossRef]

173. Huang, Q.; Zhang, X. Emerging Roles and Research Tools of Atypical Ubiquitination. Proteomics 2020, 20, 1900100. [CrossRef] [PubMed]

174. Dammermann, A.; Merdes, A. Assembly of centrosomal proteins and microtubule organization depends on PCM-1. J. Cell Biol. 2002, 159, 255-266. [CrossRef] [PubMed] 
175. Shinde, S.R.; Nager, A.R.; Nachury, M.V. Lysine63-linked ubiquitin chains earmark GPCRs for BBSome-mediated removal from cilia. bioRxiv 2020. Available online: https://www.biorxiv.org/content/10. 1101/2020.03.04.977090v1 (accessed on 17 August 2020).

176. Bhagwat, S.R.; Hajela, K.; Kumar, A. Proteolysis to Identify Protease Substrates: Cleave to Decipher. Proteomics 2018, 18, e1800011. [CrossRef] [PubMed]

177. Wu, H.Q.; Baker, D.; Ovaa, H. Small molecules that target the ubiquitin system. Biochem Soc. Trans. 2020, 48, 479-497. [CrossRef] [PubMed]

178. Ran, X.; Gestwicki, J.E. Inhibitors of protein-protein interactions (PPIs): An analysis of scaffold choices and buried surface area. Curr. Opin. Chem. Biol. 2018, 44, 75-86. [CrossRef]

179. Andrei, S.A.; Sijbesma, E.; Hann, M.; Davis, J.; O’Mahony, G.; Perry, M.W.D.; Karawajczyk, A.; Eickhoff, J.; Brunsveld, L.; Doveston, R.G.; et al. Stabilization of protein-protein interactions in drug discovery. Expert Opin. Drug Discov. 2017, 12, 925-940. [CrossRef]

180. Huang, X.; Dixit, V.M. Drugging the undruggables: Exploring the ubiquitin system for drug development. Cell Res. 2016, 26, 484-498. [CrossRef]

181. Wu, L.; Grigoryan, A.V.; Li, Y.; Hao, B.; Pagano, M.; Cardozo, T.J. Specific small molecule inhibitors of Skp2-mediated p27 degradation. Chem. Biol. 2012, 19, 1515-1524. [CrossRef]

182. Ganoth, D.; Bornstein, G.; Ko, T.K.; Larsen, B.; Tyers, M.; Pagano, M.; Hershko, A. The cell-cycle regulatory protein Cks1 is required for SCF(Skp2)-mediated ubiquitinylation of p27. Nat. Cell Biol. 2001, 3, 321-324. [CrossRef]

183. Spruck, C.; Strohmaier, H.; Watson, M.; Smith, A.P.; Ryan, A.; Krek, T.W.; Reed, S.I. A CDK-independent function of mammalian Cks1: Targeting of SCF(Skp2) to the CDK inhibitor p27Kip1. Mol. Cell 2001, 7, 639-650. [CrossRef]

184. Das, T.; Shin, S.C.; Song, E.J.; Kim, E.E. Regulation of Deubiquitinating Enzymes by Post-Translational Modifications. Int. J. Mol. Sci. 2020, 21, 4028. [CrossRef] [PubMed]

185. Das, T.; Kim, E.E.; Song, E.J. Phosphorylation of USP15 and USP4 Regulates Localization and Spliceosomal Deubiquitination. J. Mol. Biol 2019, 431, 3900-3912. [CrossRef]

186. Yamanaka, S.; Sato, Y.; Oikawa, D.; Goto, E.; Fukai, S.; Tokunaga, F.; Takahashi, H.; Sawasaki, T. Subquinocin, a small molecule inhibitor of CYLD and USP-family deubiquitinating enzymes, promotes NF- $\mathrm{B}$ signaling. Biochem. Biophys. Res. Commun. 2020, 524, 1-7. [CrossRef] [PubMed]

187. Dufner, A.; Knobeloch, K.P. Ubiquitin-specific protease 8 (USP8/UBPy): A prototypic multidomain deubiquitinating enzyme with pleiotropic functions. Biochem. Soc. Trans. 2019, 47, 1867-1879. [CrossRef]

188. Murtaza, M.; Jolly, L.A.; Gecz, J.; Wood, S.A. La FAM fatale: USP9X in development and disease. Cell. Mol. Life Sci. 2015, 72, 2075-2089. [CrossRef] [PubMed] 